
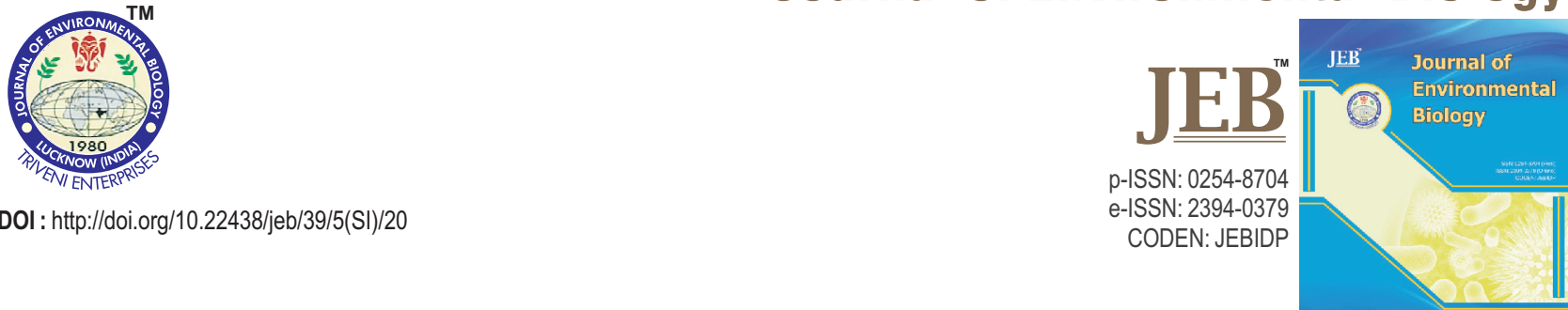

\title{
Age, growth, population dynamics and stock status of Perna perna in Omani waters
}

Authors Info

S.M. Al-Barwani ${ }^{1 *}$, S.M. Nurul Amin ${ }^{2}$, A. Arshad ${ }^{2}$, A. Govender', H. Al-Habsi', K. Al-Riyami ${ }^{1}$ and Jassim A. Al Khayat ${ }^{3}$

'Department of Marine Science and Fisheries, College of Agricultural and Marine Sciences, Sultan Qaboos University, P. O. Box 34, PC 123, Sultanate of Oman

${ }^{2}$ Department of Aquaculture, Faculty of Agriculture, Universiti Putra Malaysia, 43400 Serdang, Selangor, Malaysia

${ }^{3}$ Department of Biological and Environmental Sciences, College of Arts and Science, Qatar University, P.O. Box 2713, Doha, Qatar

*Corresponding Author Email : sharthi@squ.edu.om.

\section{Key words}

Exploitation rate

Growth performance index

Mortality

Perna perna

Stock status

\section{Publication Info}

Paper received : 26.04.2017

Revised received : 17.08.207

Re-revised received : 05.09.2017

Accepted : 28.12.2017

\section{Abstract}

Aim : Population parameters such as growth, recruitment pattern, mortality, exploitation rate and the length-weight relationship were investigated for the brown mussel, Perna perna in Omani waters.

Methodology : Monthly shell-length frequency of $P$. perna were collected from three different locations, namely, Mirbat, Ra's Al-Had and Ra's Madrakah for one year from December 2010 to November 2011. The data were analysed using the FiSAT (FAO-ICLARM Stock Assessment Tools) software to estimate population parameters.

Results : The length of individuals ranged from 10.34 to $104.03 \mathrm{~mm}$ and the weight from 0.12 to $52.45 \mathrm{~g}$. The estimated relative growth coefficient (b) was $3.079( \pm 0.019)$, and the $95 \%$ confidence level of $b$ ranged from 3.045 to 3.116 . The annual recruitment pattern of $P$. perna showed a continuous trend throughout the year. The peak recruitment at Mirbat (19\%) and Ra's Al Had (21\%) was observed in June, whereas at Ra's Madrakah (24\%) it was observed in July. The estimated total mortality values of $P$. perna were $2.84 \mathrm{yr}^{-1}, 3.28$ $\mathrm{yr}^{-1}$ and $2.48 \mathrm{yr}^{-1}$ at Mirbat, Ra's Al Had and Ra's Madrakah, respectively, while the natural mortality rates were $1.25 \mathrm{yr}^{-1}$ at Mirbat, $1.29 \mathrm{yr}^{-1}$ at Ra's Al Had, and $1.23 \mathrm{yr}^{-1}$ at Ra's Madrakah. The fishing mortality rates were $1.59 \mathrm{yr}^{-1}$ at Mirbat, $1.99 \mathrm{yr}^{-1}$ at Ra's Al Had and $1.25 \mathrm{yr}^{-1}$ at Ra's Madrakah. The Perna perna attained an approximate length of $53.5 \mathrm{~mm}$ at the end of one year. Exploitation rate $(E)$ was $0.56,0.60$ and 0.50 at Mirbat, Ra's Al Had and Ra's Madrakah, respectively.

Interpretation : The results revealed that the stock of $P$. perna at Mirbat and Ra's Al Had areas was over exploited. However, currently at Ra's Madrakah the stock of $P$. perna is currently optimally exploited.

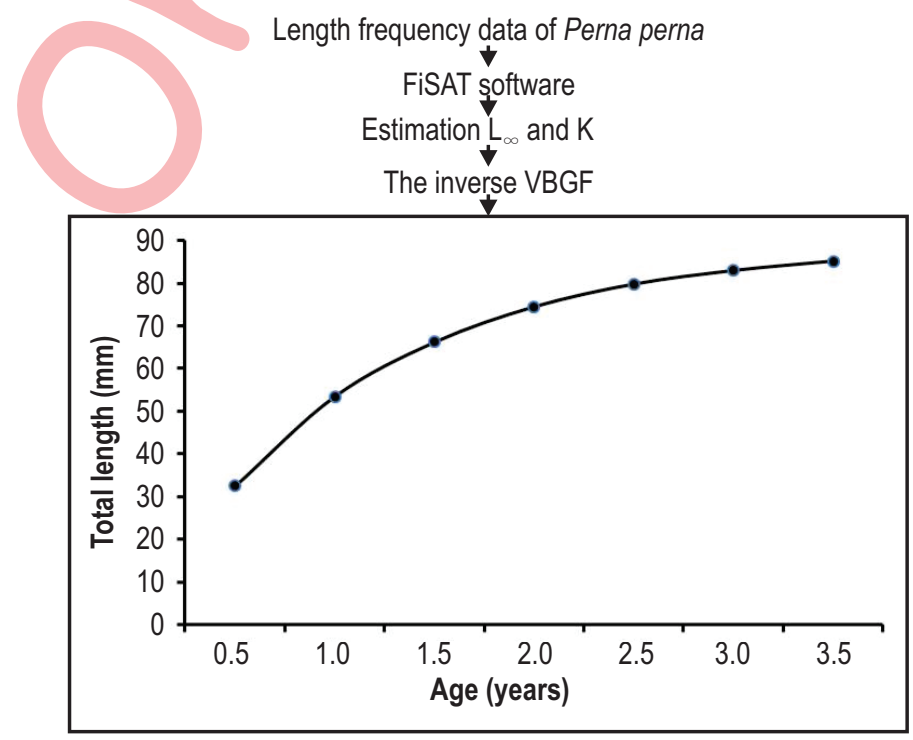




\section{Introduction}

The brown mussel, Perna perna is abundant on rocky shores along the coastal areas of the Arabian Sea of the Sultanate of Oman (Al-Barwani et al., 2013). This species is considered endemic to Yemen, southern India, Sri Lanka, Madagascar, the southwestern Indian Oceans along the east coast of Africa, north of Luderiz Bay, the Mediterranean from Gibraltar to the Gulf of Tunis, the central and southwestern Atlantic Ocean along the coasts of Brazil, Uruguay, Venezuela, the West Indies, and recently colonized much of the Texan coast of the Gulf of Mexico (Hicks and Tunnell, 1995; Hicks et al., 2001; Sokolowski et al., 2010). The brown mussel in Oman has little economic value due to limited demands by the local people, and is only consumed by local coastal communities where it is prolific. However, recently the demand for imported mussels from Europe and New Zealand has increased due to the demand from the increasing expatriate communities in Oman. Nowadays, P. perna has gained some economic importance due the demand from hotels and seafood restaurants which cater to tourists and the expatriate communities.

The purpose of fish population dynamics studies in open waters, where recruitment is a natural process, is to assess the stock size to provide advice on its optimum exploitation level. Fish stock assessment describes the exploitation level in both time and space. Thus, studies on population dynamics and assessment of a stock in an open water fishery are of the utmost importance, as it is a means to guide effective fisheries management based on scientific principles, with the aim to achieve a sustainable yield.

Knowledge of important population parameters such as growth, recruitment, mortality, exploitation rate, amongst others, are required as stock assessment input parameters that lead to effective fisheries management norms. In spite of its great importance, little is known about $P$. perna in Omani waters. Therefore, the present study was undertaken to estimate the key population parameters and exploitation levels of $P$. perna in order to assess the stock status of the species in the Sultanate of Oman.

\section{Materials and Methods}

Monthly total wet weight in gram and shell total length frequency data in millinetrem of $P$. perna were collected from three different locations in Omani waters, namely, Mirbat, Ra's AlHad and Ra's Madrakah (Fig. 1) from December 2010 to November 2011. The collected shell length frequency data were grouped into length classes at $4 \mathrm{~mm}$ intervals. The data were analysed using the FiSAT (FAO-ICLARM Stock Assessment Tools) software (Gayanilo et al., 1996) to estimate the mortality and the von Bertalanffy growth parameters. Asymptotic length $(L$ $\left.\infty_{\infty}\right)$ and growth co-efficient (K) of the von Bertalanffy growth equation (VBGE) were estimated by means of ELEFAN-1 (Pauly and David, 1981; Saeger and Gayanilo, 1986). A growth performance for $P$. perna was calculated using the growth performances index $\left(\varphi^{\prime}\right)$ equation: $\varphi^{\prime}=2 \log _{10} L \infty+\log _{10} K$ (Pauly and Munro, 1984). The inverse VBGF (Sparre and Venama, 1992) was used for determining $P$. perna length at various ages. The inverse VBGF is expressed by the following equation:

$$
L_{t}=L\left[1-e^{-k(t-t)}\right]
$$

Where, $L_{t}=$ mean length at age $t ; L=$ asymptotic length; $K=$ growth co-efficient; $\mathrm{t}=$ age of the $P$. perna and $\mathrm{t}_{0}=$ the hypothetical age at which the length is zero (Newman, 2002).

To establish the length-weight relationship, the cubic or power curve equation $W=a L^{b}$ was applied (Ricker, 1975; Quinn II and Deriso, 1999). Where $W$ is the weight (g); $L$ is the total length $(\mathrm{mm})$ and ' $a$ ' and ' $b$ ' are constants. The parameters $a$ and $b$ were estimated by least squares linear regression on log-log transformed data: $\log _{10} W=\log _{10} a+b \log _{10} L$. The coefficient of determination $\left(r^{2}\right)$ was used as an indicator of the quality of the linear regressing (Scherrer, 1984). Additionally, 95\% confidence limits of the parameters a and b were estimated, and the statistical significance level of $r^{2}$ was also estimated.

Natural mortality rate $(\mathrm{M})$ was estimated by the equation given below (Pauly, 1980):

$\log _{10} M=-0.0066-0.279 \log _{10} L_{\infty}+0.6543 \cdot \log _{10} K+0.4634 \log _{10} T$

Table 1: Comparison of population parameters for three different stations in Sultanate of Omani waters

\begin{tabular}{llll}
\hline Parameters & Mirbat & Ra's Al Had & Ra's Madrakah \\
\hline Asymptotic length $\left(\mathrm{L}_{\infty}\right)$ in mm & 71.40 & 88.20 & 107.10 \\
Growth co-efficient $\left(\mathrm{K} \mathrm{yr}^{-1}\right)$ & 0.84 & 0.94 & 0.95 \\
Growth performance index $\left(\varphi^{\prime}\right)$ & 3.63 & 3.86 & 4.04 \\
Natural mortality $\left(\mathrm{M} \mathrm{yr}^{-1}\right)$ & 1.25 & 1.29 & 1.23 \\
Fishing mortality $\left(\mathrm{F} \mathrm{yr}^{-1}\right)$ & 1.59 & 1.99 & 1.25 \\
Total mortality $\left(\mathrm{Z} \mathrm{yr} \mathrm{r}^{-1}\right)$ & 2.84 & 3.28 & 2.48 \\
Exploitation rate $(\mathrm{E})$ & 0.56 & 0.60 & 0.50 \\
Sample size $(\mathrm{n})$ & 2920 & 2297 & 2085 \\
Length range $(\mathrm{mm})$ & $10-80$ & $12-84$ & $16-104$ \\
Weight range $(\mathrm{g})$ & $0.12-34.28$ & $0.44-29.12$ & $0.52-52.45$ \\
\hline
\end{tabular}




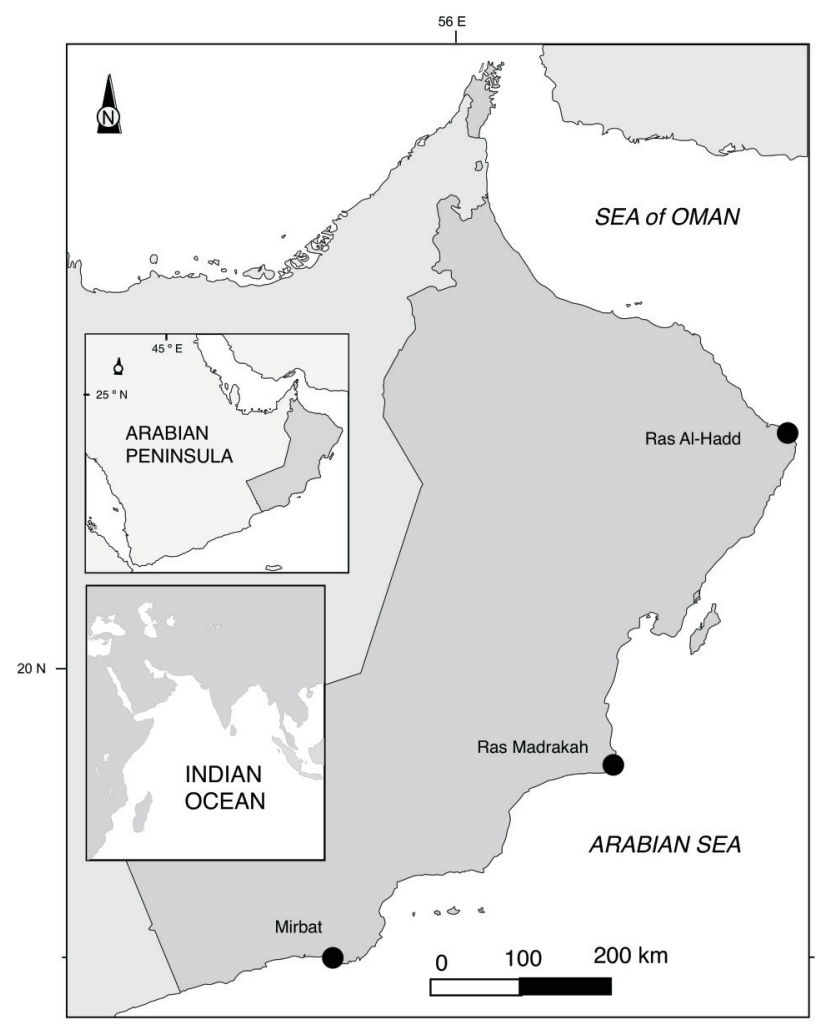

Fig. 1 : Sampling locations of brown mussel Perna perna (shown as by black dots)

Where, $M$ is the instantaneous natural mortality; $L_{\infty}$ the asymptotic length; $K$ refers to the growth co-efficient of the VBGF and $T$ is the mean annual habitat temperature of the water in which the stocks live (Pauly, 1980).

Jones and van Zalinge plot (Jones and van Zalinge 1981) was used to estimate total mortality (Z). Fishing mortality (F) was estimated by the following formula: $F=Z-M$.

Where, $\mathrm{Z}$ is the total mortality and $\mathrm{M}$ is natural mortality. Exploitation rate (E) was calculated as F/Z (Gulland, 1971).

A routine in FiSAT reconstructs the recruitment pulse from a time series of length-frequency data to determine the number of pulses per year and the relative strength of each pulse, using the von Bertalanffy growth parameters $\mathrm{L}_{\infty}, \mathrm{K}$ and $\mathrm{t}_{0}\left(\mathrm{t}_{0}=0\right)$. Normal distribution of the recruitment pattern was determined by NORMSEP in FiSAT (Gayanilo et al., 1996).

\section{Results and Discussion}

Growth parameters: The values of various population parameters obtained during the present study are given in Table 1. It was observed that the asymptotic lengths $\left(L_{\infty}\right)$ was calculated as $71.40 \mathrm{~mm}$ in Mirbat, $88.20 \mathrm{~mm}$ in Ra's Al Had and
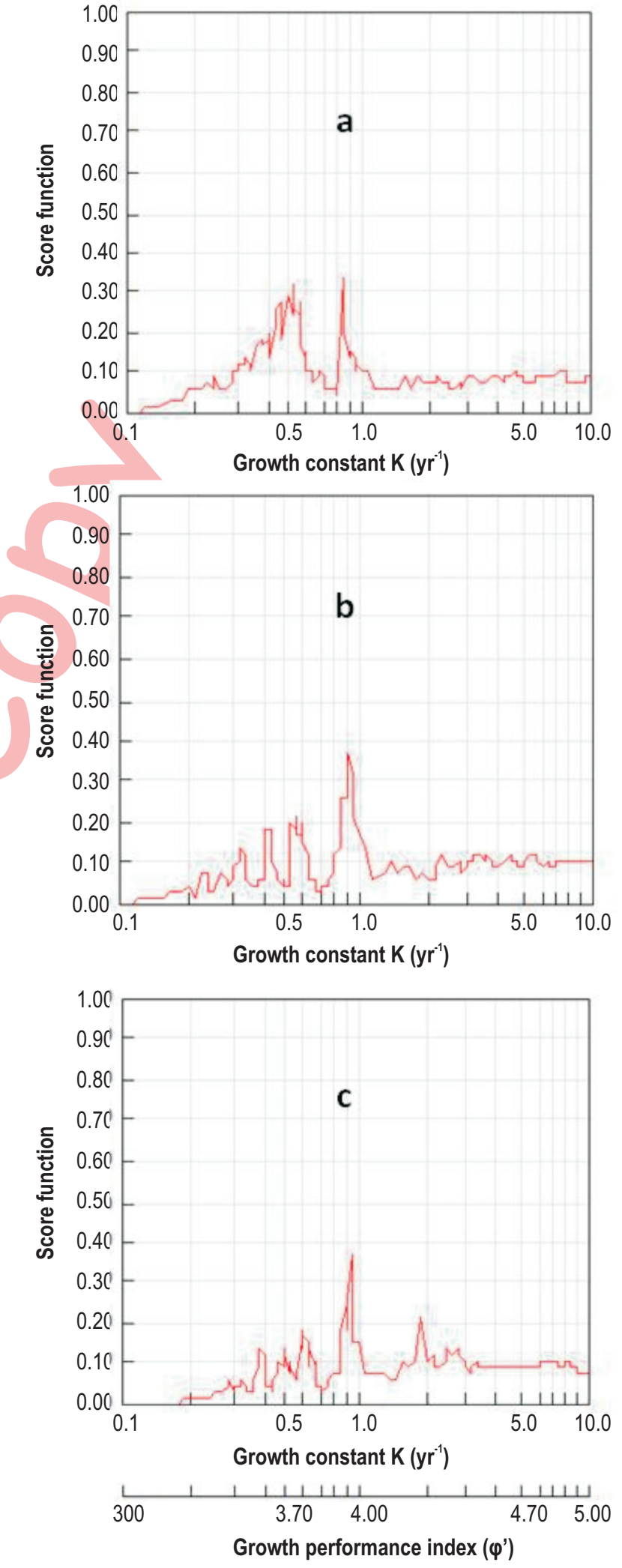

Fig. 2 : K-scan routine for determination of the best growth curvature giving the best value of $\mathrm{K}$ for Perna perna at (a) Mirbat; (b) Ra's Al Had and (c) Ra's Madrakah 
$107.10 \mathrm{~mm}$ in Ra's Madrakah. The highest values of the growth co-efficient (K) were $0.84 \mathrm{yr}^{-1}$ in Mirbat (Fig. 2a), 0.94 in Ra's Al Had (Fig. 2b) and 0.95 in Ra's Madrakah (Fig. 2c). The growth curves of $P$. perna superimposed over their restructured lengthfrequency data for three sampling sites (Fig. 3a-c) The largest asymptotic length was observed in Ra's Madrakah and lowest at Mirbat. The asymptotic length $\left(L_{\infty}\right)$ values of $P$. viridis recorded by Al-Barwani et al. (2007) in the coastal waters of Malacca and by Amin et al. (2005) in Bangladesh waters were much higher (Table 2) than the values observed at Mirbat and Ra's Al Had. However, the $L_{\infty}$ reported by Al-Barwani et al. (2007) was more or less similar to the value found at Ra's Madrakah waters. This could be due the heavy pressure imposed on the mussel stock at both Mirbat and Ra's Al Had leading to a lower $\mathrm{L}_{\infty}$. The mussel beds at the two sites are confined and easily accessible by a large number of collectors who target large sized animals. However, at
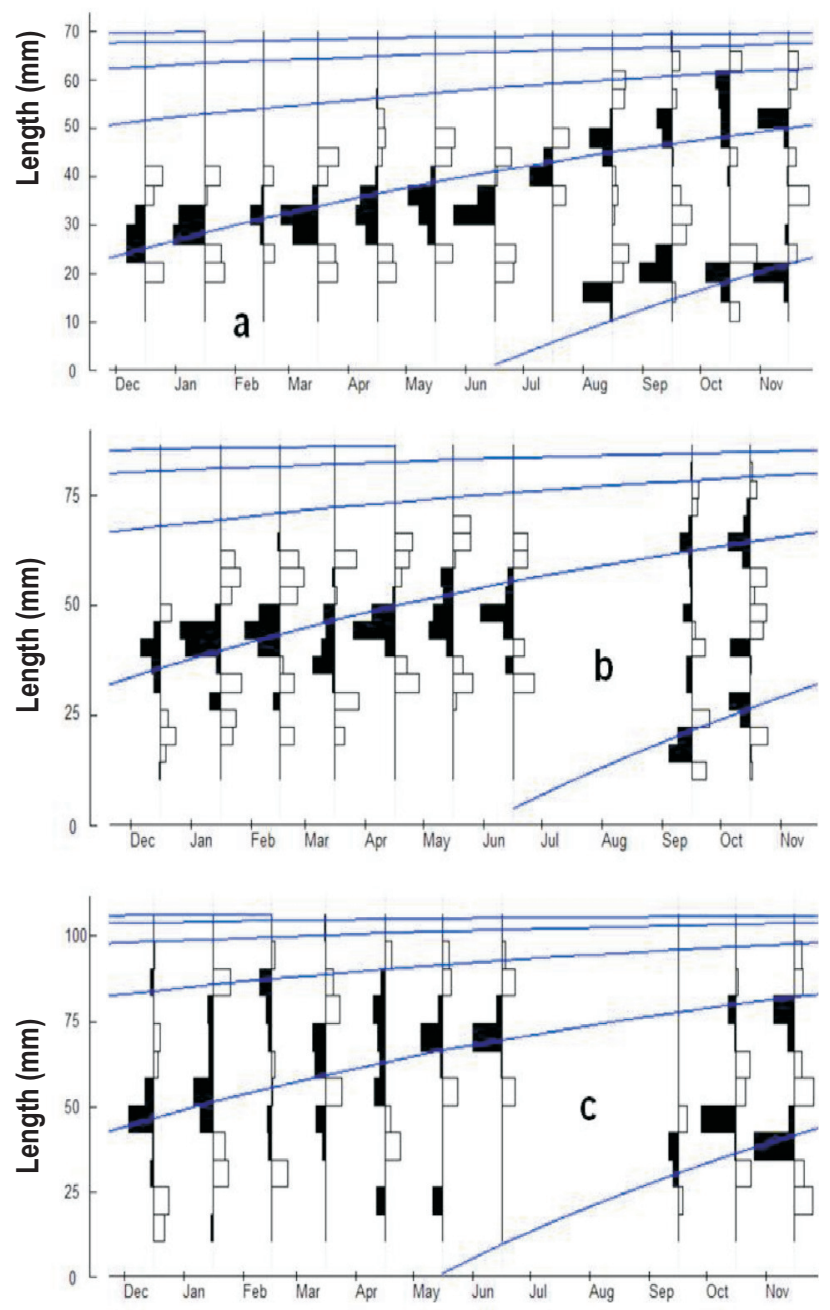

Fig. 3 : Von Bertalanffy growth curves of Perna perna at (a) Mirbat, (b) Ra's Al Had and (c) Ra's Madrakah superimposed on the restructured length-frequency histograms
Ra's Madrakah the mussel beds are widely spread and are difficult to access which gives opportunity for the mussels to grow larger because of the lower fishing pressure.

The growth co-efficient, $\mathrm{K}$ values of $P$. perna, varied between $0.84 \mathrm{yr}^{-1}$ and $0.95 \mathrm{yr}^{-1}$ among the three stations. The mean $\mathrm{K}$ value which represents the coastal waters of Oman was $0.91 \mathrm{yr}^{-1}$. This value, however, is a little bit higher than the value of $\mathrm{K}$ obtained for $P$. viridis from Bangladesh, India and Hong-Kong and lower than Thailand and Malaysia (Table 2). This could be due to the fact that shell growth rate in tropical pernids is greater than that found in temperate mytilids (Vakily, 1989; Hicks et al., 2001). The species $P$. perna in its native geographical distribution is known for its rapid growth rate which enables the animal to reach a size of $50-70 \mathrm{~mm}$ in $6-7$ months (Chung and Acuna, 1981; Sokolowski etal., 2010).

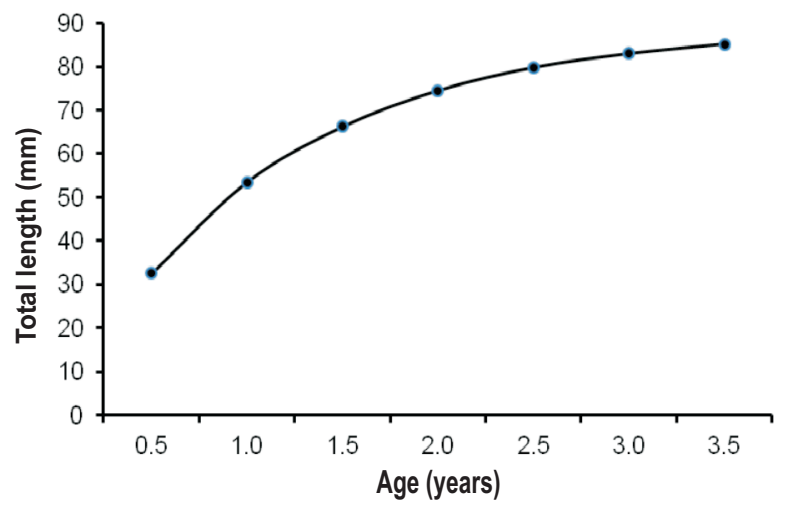

Fig. 4 : Plot of age and growth of Perna perna based on computed growth parameters

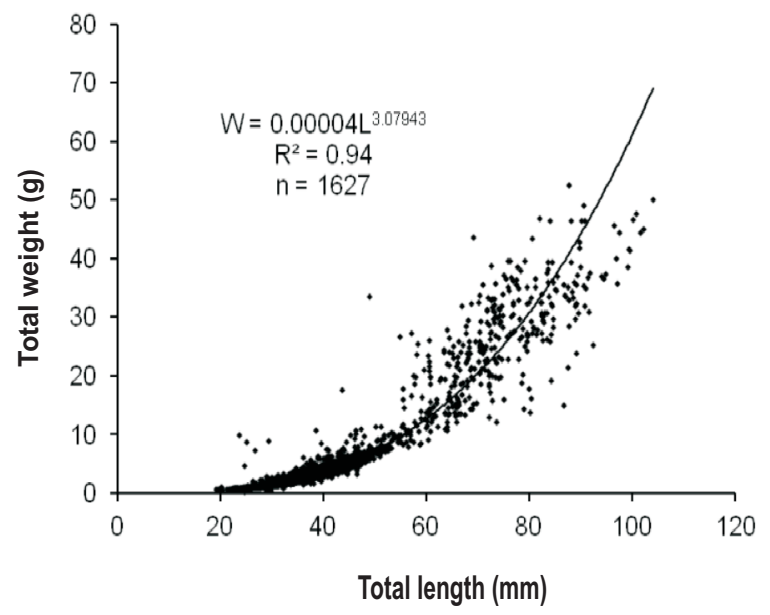

Fig. 5 : Length-weight relationship of Perna perna from Omani waters for both sexes 
Table 2 : Parameter values of von Bertalanffy growth function for Perna viridis from different countries and Perna perna from Oman

\begin{tabular}{|c|c|c|c|c|c|c|}
\hline Location & Species & $\underline{\mathrm{L}_{\infty}(\mathrm{mm})}$ & $\mathrm{K} \mathrm{yr}^{-1}$ & $\varphi^{\prime}$ & $\mathrm{T}\left({ }^{\circ} \mathrm{C}\right)$ & Source \\
\hline Oman & P. perna & 88.90 & 0.91 & 3.84 & - & Present study \\
\hline Malaysia & $P$. viridis & 102.3 & 1.50 & 4.19 & 29.4 & Al-Barwani et al. (2007) \\
\hline Bangladesh & P. viridis & 194.3 & 0.56 & 2.32 & 28.0 & Amin et al. (2005) \\
\hline India & $P$. viridis & 184.6 & 0.25 & - & - & Narasimham (1981) \\
\hline Thailand & P. viridis & 112.0 & 1.00 & - & - & Tuaycharoen et al. (1988) \\
\hline Hong Kong & P. viridis & 101.9 & 0.30 & - & - & Lee (1985) \\
\hline
\end{tabular}

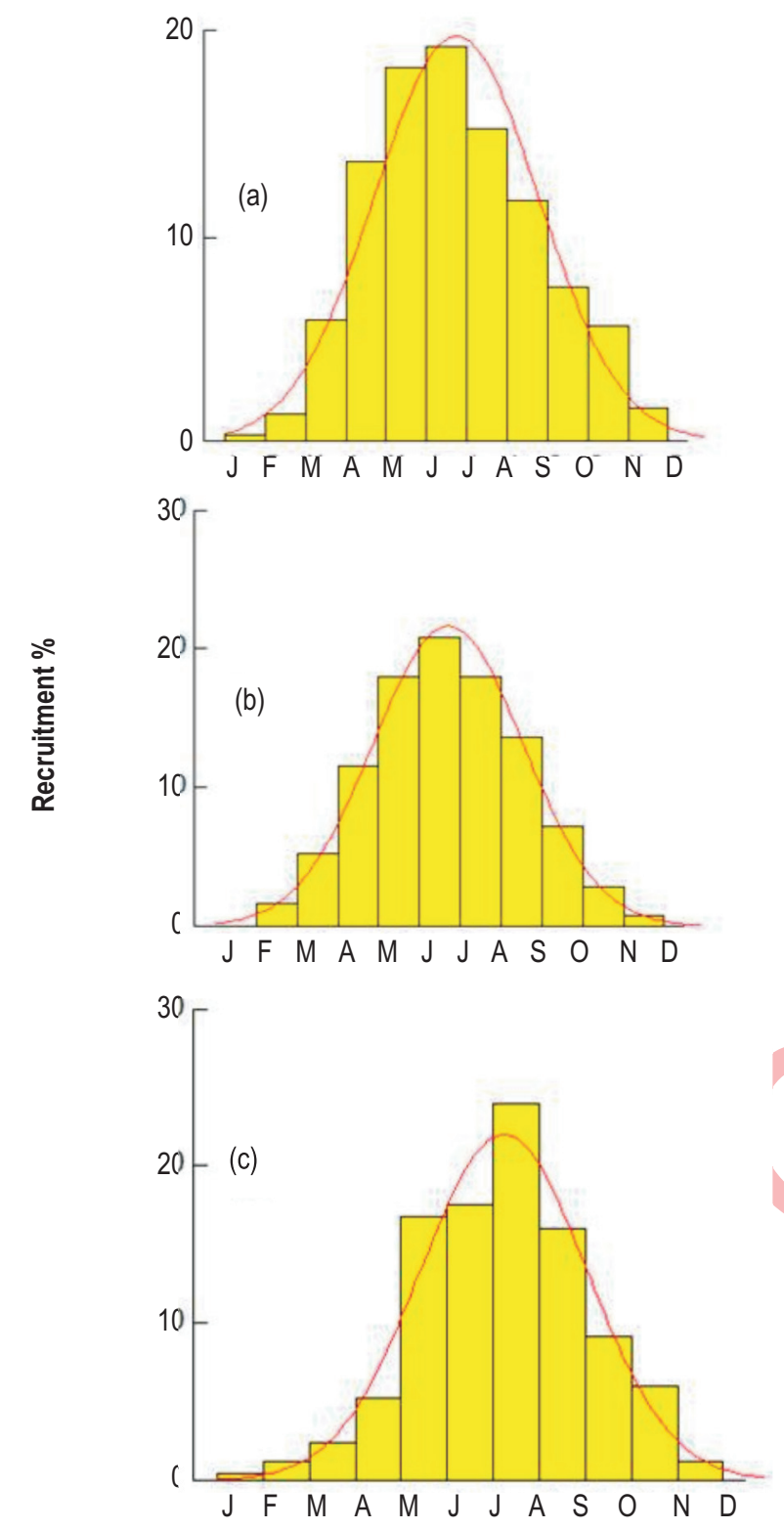

Fig. 6 : (a) Annual recruitment pattern of Perna perna at Mirbat, (b) Ra's AlHad and (c) Ra's Madraka
The growth performance index $\left(\varphi^{\prime}\right)$ values of $P$. perna different locations were found to be high and varied between 3.63 and 4.04 (Table 1). These values differed very little among the three locations despite varying fishing mortalities. P. perna distribution in the coastal waters of Oman is only along the Arabian Sea. The Arabian Sea is characterised to be one of the most highly productive regions of the world's oceans (Nair et al., 1989), and this will definitely have an effect on the growth performance of $P$. perna.

Age and growth : The sizes attained by P. perna were $32.5 \mathrm{~mm}$, $53.5 \mathrm{~mm}, 74.5 \mathrm{~mm}$ and $83.1 \mathrm{~mm}$ at the end of $0.5,1,2$ and 3 years of age, respectively. The absolute increase is presented in Fig. 4 The estimated growth increment was $21 \mathrm{~mm}$ and $8.6 \mathrm{~mm}$ from $1^{\text {st }}$ to $2^{\text {nd }}$ and $2^{\text {nd }}$ to $3^{\text {rd }}$ year, respectively. Similar studies were conducted and reported on P. viridis by Amin et al. (2005) and AlBarwani et al. (2007) and on Crassostrea madrasensis by Amin et al. (2008), by inverse VBGF which was also followed in this study.

Length-weight relationship : The length size and the weight of individuals ranged from 10.34 to $104.03 \mathrm{~mm}$ (Table 1) and the weight from 0.12 to $52.45 \mathrm{~g}$ at three sites. The length-weight relationship curve is presented in Fig. 5 . The calculated lengthweight equation was $\log W=-4.3724+3.0794 \log \mathrm{L}$.

In exponential form the equation was $\mathrm{W}=0.00004 \mathrm{~L}^{3.0794}(\mathrm{r}$ $\left.{ }^{2}=0.94, p<0.01\right)$. The estimated relative growth coefficient $(b)$ was $3.079( \pm 0.019)$. The $95 \%$ confidence level for the parameter $b$ ranged from 3.045 to 3.116 . The growth coefficient $b$ generally lies between 2.5 and 3.5 and the length-weight relationship is said to be isometric when it is equal to 3 (Carlander, 1977). In the present case, the estimated $b(3.079)$ was very close to the isometric value mentioned by Carlander (1977). This indicates the isometric nature of growth for $P$. perna in the coastal waters of Oman.

Recruitment pattern : The annual recruitment pattern of $P$. perna was continuous throughout the year with one major peak in all the investigated areas (Fig. 6a-c). The peak recruitment values calculated by FiSAT were $19 \%$ at Mirbat, $21 \%$ at Ra's Al Had during the month of June and 24\% in Ra's Madrakah during the month of July. The results revealed that the recruitment pattern 
three different locations consisted of one seasonal pulse, i.e., one cohort is produced per year and the highest peak occurs in MayAugust. There is no published report on recruitment of $P$. perna in Oman for comparison. Al-Barwani et al. (2007) reported a single cohort of recruitment for $P$. viridis in the coastal waters of Malaysia, which is similar to the present study's findings.

Mortality and exploitation : The estimated total mortality values of P. perna were $2.84 \mathrm{yr}^{-1}$ at Mirbat, $3.28 \mathrm{yr}^{-1}$ at Ra's Al Had and $2.48 \mathrm{yr}^{-1}$ at Ra's Madrakah (Table 1). The natural mortality rates of P. perna were $1.25 \mathrm{yr}^{-1}$ at Mirbat, $1.29 \mathrm{yr}^{-1}$ at Ra's Al Had and 1.23 $\mathrm{yr}^{-1}$ at Ra's Madrakah. The fishing mortality rates of $P$. perna were $1.59 \mathrm{yr}^{-1}$ at Mirbat, $1.99 \mathrm{yr}^{-1}$ at Ra's Al Had and $1.25 \mathrm{yr}^{-1}$ at Ra's Madrakah. The fishing mortality was higher than natural mortality at Mirbat and Ra's Al Had site. However, at Ra's Madrakah the rate of fishing mortality was more or less similar to natural mortality. Exploitation level $E$ of $P$. perna was $0.56,0.60$ and 0.50 at Mirbat, Ra's Al Had and Ra's Madrakah, respectively. The exploitation rates, $E$ for $P$. perna revealed that the stock of $P$. perna in Mirbat and Ra's Al Had areas was over exploited. However, at Ra's Madrakah the stock of $P$. perna was in the process of becoming optimally exploited.

According to Gulland (1965), the yield is optimized when $\mathrm{F}=\mathrm{M}$; therefore, when $\mathrm{E}$ is more than 0.50 , the population stock is considered over-fished. The higher value of $E(E>0.50)$ indicates the 'over-fishing' condition of $P$. perna in Mirbat and Ra's Al Had areas. It could be concluded that the resource of $P$. perna is under heavy pressure in Mirbat and Ra's Al Had areas. Hence, Ra's Madrakah, which has a difficult access terrain, should be protected as it can serve as a source of recruitment for the other two more heavily exploited areas.

\section{Acknowledgments}

The authors would like to express their sincere gratitude to the Agriculture and Fisheries Development Fund for funding this study. We also thanks Dr. Hussein Al-Masrooriand Dr. Ahmed Al-Maskri for this help in running this project.

\section{References}

Al-Barwani, S.M., A. Arshad, S.M.N. Amin, S.B. Japar, S.S. Siraj and C.K. Yap: Population dynamics of the green mussel Perna viridis from the high spat-fall coastal water of Malacca, Peninsular Malaysia. Fisheries Research, 84, 147-152 (2007).

Al-Barwani, S.M., D. Aziz, S.M.N. Amin and A. Arshad: Microsatellite DNA marker analysis in brown mussels, Perna perna (Linnaeus, 1758) from the coastal waters of Oman. Asian J. Animal Veter. Adv., 8, 317-324 (2013).

Amin, S.M.N., M. Zafar and A. Halim: Age, growth, mortality and population structure of the oyster, Crassostrea madrasensis, in the Moheskhali Channel (southeastern coast of Bangladesh). J. Appl. Ichthyol., 24, 18-25(2008).

Amin, S.M.N., M.A. Halim, M. Barua and A. Arshad: Population dynamics and exploitation level of green-lipped mussel (Perna viridis) using
FiSAT from the offshore island of the Cox's Bazar coast of Bangladesh. Pertanika J. TropicalAgri. Sci., 28, 103-109 (2005).

Carlander, K.: Handbook of Freshwater Fishery Biology. lowa Ames, IA: State University Press (1977).

Chung, K.S. and A. Acuna: Upper temperature tolerance limit of mussel, Perna perna. Bull. Japanese Soc. Sci. Fisheries, 47, 441 (1981).

Gayanilo, J.F.C., P. Soriano and D. Pauly : The FAO-ICLARM stock assessment tools (FiSAT) users guide. FAO Computerised Information Series (Fisheries). No. 8. Rome, FAO, 266 (1996).

Gulland, J.A.: Estimation of mortality rates. Annex to Artic fisheries working group report. ICES C. M. Doc. 3 (mimeo) (1971).

Gulland, J.A.: Manual of methods for fish stock assessment. Part I. Fish population analysis. FAO Fisheries Technical Papers No. 40. Revised 1 (1965).

Hicks, D.W. and J.W.J. Tunnell: Ecological notes and patterns of dispersal in the recently introduced mussel, Perna perna (Linné, 1758), in the Gulf of Mexico. American Malacological Bulletin, 11, 203-206 (1995).

Hicks, D.W., J.W.J. Tunnell and R.F. McMahon: Population dynamics of the nonindigenous Brown mussel Perna perna in the Gulf of Mexico compared to other world-wide populations. Marine Ecol. Prog. Series, 211, 181-192 (2001).

Jones, R. and N.P. van Zalinge: Estimates of mortality rate and population size for shrimp in Kuwait waters. Kuwait Bull. Marine Sci., 2, 273-288(1981).

Nair, R.R., V. Ittekkot, S.J. Manganini, V. Ramaswamy, B. Haake, E.T. Degens, B.N. Desai and S. Honjo: Increased particle fluxes to the oceans related to monsoons. Nature, 338, 749-751 (1989).

Newman, S.J.: Growth, age estimation and preliminary estimates of longevity and mortality in the moses perch, Lutjanus russelli (Indian ocean form), from continental shelf waters off northwestern Australia. Asia. Fish. Sci., 15, 283-294 (2002).

Pauly, D. : On the interrelationships between natural mortality, growth parameters and mean environmental temperature in 175 fish stocks. Journal du Conseil international pour l'Exploration de la Mer, 39, 175-192 (1980).

Pauly, D. and J.L. Munro: Once more on the comparison of growth in fish and invertebrate. Inter. Center for Living Aqua. Resour. Manag. Fishbyte, 2, 21(1984).

Pauly, D. and N. David : ELEFAN-I BASIC program for the objective extraction of growth parameters from Length frequency data. Meeresforsch , 28, 205-211 (1981).

Quinn II, T. and R.B. Deriso: Quantitative Fish Dynamics. Oxford University Press, New York (1999).

Ricker, W.E.: Computation and interpretation of biological statistics of fish populations. Bull. Fisheries Res. Board of Canada, 191, 382 (1975).

Saeger, J. and F.J. Gayanilo: A revised and graphics oriented version of ELEFAN-I and II basic programs for use on HP/86/87 microcomputers. Technical Report Department of the Marine Fish No. 8(1986)

Scherrer, B.: Biostatistique. Morin, Montreal, Paris (1984).

Sokolowski, A., A.S. Bawazir, E. Sokolowska and M. Wolowicz: Seasonal variation in the reproductive activity, physiological condition and biochemical components of the brown mussel Perna perna from the coastal waters of Yemen (Gulf of Aden). Aqua. Livi. Resour., 23, 177-186 (2010).

Sparre, P. and S.C. Venema : Introduction to tropical fish stock assessment. Part 1. manual. Food and Agricultural Organization of the United Nations, Rome, FAO Fisheries Technical Paper 306/1, 376 (1992).

Vakily, J.M.: The biology and culture of mussels of the genus Perna. Int. Center for Living Aqua. Res. Manag., Manila, Philippines, pp. 1-63 (1989). 